\title{
FROM OPPORTUNITY TO IMPERATIVE: THE HISTORY OF THE MARKET
}

\section{by ELLEN MEIKSINS WOOD}

Just about every definition of the "market" in the dictionary connotes an opportunity: as a concrete locale or institution, a market is a place where opportunities exist to buy and sell; as an abstraction, a market is the possibility of sale. Goods "find a market," and we say there is a market for a service or commodity when there is a demand for it, which means it can and will be sold. Markets are opened to those who want to sell. The market represents "conditions as regards, opportunity for, buying and selling" (The Concise Oxford Dictionary). The market implies offering and choice.

What then are market forces? Doesn't force imply coercion? In the conventional language of capitalist ideology, the market implies not compulsion but freedom. At the same time, this freedom is guaranteed by certain regulatory mechanisms which ensure a rational economy, where supply meets demand, putting on offer commodities and services that people will freely choose. These mechanisms are the impersonal "forces" of the market, and if they are in any way coercive, it is simply in the sense that they compel economic actors to act "rationally" so as to maximize choice and opportunity.

All this implies that capitalism, the ultimate "market society," is the optimal condition of opportunity and choice.

Ellen Meiksins Wood teaches political science at York University, in Ontario, Canada. Her forthcoming book, Democracy Against Capitalism: Renewing Historical Materialism is due out this winter. 
More goods and services are on offer, more people are more free to sell and profit from them, and more people are more free to choose among and buy them.

So what is wrong with this picture? A socialist is likely to tell you that the major missing ingredient is the commodification of labor power and class exploitation. So far so good. But what may not always be so clear, even in socialist accounts of the market, is that the distinctive and dominant characteristic of the capitalist market is not opportunity or choice but, on the contrary, compulsion. Material life and social reproduction in capitalism are universally mediated by the market, so that all individuals must in one way or another enter into market relations in order to gain access to the means of life; and the dictates of the capitalist market-its imperatives of competition, accumulation, profit maximization, and increasing labor productivity-regulate not only all economic transactions but social relations in general. As relations among human beings are mediated by the process of commodity exchange, social relations among people appear as relations among things, the "fetishism of commodities" in Marx's famous formula.

Some readers are likely to object here that this is something every socialist, or at least every Marxist, knows; but I have my doubts. In what follows, I shall argue that most historical accounts of capitalism, both right and left, have tended to lose sight of its historical specificity, the peculiarity of the capitalist market as a compulsion rather than an opportunity. I think it follows that our understanding of capitalism today, and of the political possibilities available to a socialist opposition, will be affected by how we understand its history, the particular ways in which it represents a historic rupture with earlier social forms, and what this tells us about the specificities of the capitalist market.

Far from recognizing that the market became capitalist when it became compulsory, most historical accounts suggest 
that capitalism emerged when the market was liberated from age-old constraints and when, for one reason or another, opportunities for trade expanded. In these accounts, capitalism represents not so much a radical qualitative break from earlier forms as a massive quantitative increase, an expansion of markets, and a growing commercialization of economic life. The traditional account-which appears in classical political economy, Enlightenment conceptions of progress, and many more modern histories-goes something like this:

With or without a natural inclination to "truck, barter and exchange" (in Adam Smith's famous phrase), rationally self-interested individuals have been engaging in acts of exchange since the dawn of history. These acts became increasingly specialized with an evolving division of labor, which was also accompanied by technical improvements in the instruments of production (improvements in productivity, in many of these explanations, may in fact have been the primary purpose of the increasingly specialized division of labor, so that there tends to be a close connection between these accounts of commercial development and a kind of technological determinism). And capitalism-or "commercial society," the highest stage of progress-represents a maturation of age-old commercial practices and their liberation from political and cultural constraints.

But only in the West, the story goes, were these constraints comprehensively and decisively lifted. In the ancient Mediterranean, "commercial society" was already fairly well established, but its further evolution was interrupted by an unnatural break-the hiatus of feudalism, and several "dark" centuries during which economic life was again fettered by irrationalism and the political parasitism of landlordly power. The classic explanation of this interruption invokes "barbarian" invasions of the Roman Empire, but a later and very influential version of this model was elaborated, from the 1890s through the 1920s, by the Belgian historian Henri Pirenne, who situated the rupture of the Mediterranean commercial civilization rather later, in the Muslim invasion which, 
he argued, suppressed the old commercial system by closing off the Mediterranean trade routes between East and West. A growing "economy of exchange," led by a professional class of merchants, was replaced by an "economy of consumption," the rentier economy of the feudal aristocracy.

But eventually, according to both Pirenne and his predecessors, commerce revived with the growth of cities and the liberation of merchants. This time, however, there emerged cities with a distinctive and unprecedented autonomy, cities devoted to trade and dominated by an autonomous burgher class which was to free itself once and for all from the fetters of the old cultural constraints and political parasitism. This liberation of the urban economy, of commercial activity and mercantile rationality (accompanied by the inevitable improvements in techniques of production which evidently follow from the emancipation of trade), was apparently enough to account for the rise of modern capitalism.

There have been other refinements of the old "commercialization" model, from Weber to Braudel. ${ }^{2}$ There have also been frontal attacks on the "commercialization model" in general and the Pirenne thesis in particular (now generally out of favor). The most influential and currently more or less hegemonic of these has been the demographic model, which attributes European economic development to certain autonomous cycles of population growth and decline. But however vehemently the old model has been challenged, its fundamental presuppositions seem to have remained intact. In one way or another, whether by processes of urbanization and growing trade or by the cyclical patterns of demographic growth, the transition to capitalism in all these explanations is a response to the universal and transhistorical laws of the market, the laws of supply and demand. ${ }^{3}$

There is, of course, a major paradox here. The conception of the market as an arena of choice, and "commercial society" as the perfection of freedom, has tended to be associated with a theory of history in which modern capitalism is the outcome of an almost natural process, following certain 
universal, transhistorical, and immutable laws. The operation of these laws can, at least temporarily, be obstructed, but not without great cost. And its end-product, the "free" market, is an impersonal mechanism, which can to some extent be controlled and regulated, but which cannot finally be thwarted without all the dangers-and the futility-involved in any attempt to violate the laws of nature.

All these explanations have in common certain assumptions about the continuity of trade and markets, from their earliest manifestations in primitive acts of exchange to their maturity in modern industrial capitalism. The age-old practice of commercial profit-taking in the form of "buying cheap and selling dear" is not, in these models, fundamentally different from capitalist exchange and accumulation through the appropriation of surplus value. Certainly there was a major shift from feudalism to capitalism, but the transformation was not in the nature of trade and markets themselves. The change was rather in what happened to the forces and institutions-political, legal, cultural, ideological as well as technological-that had impeded the natural evolution of trade and the maturation of markets.

If anything, in these models it is feudalism that represents the real historic rupture; and while the resumption of commercial development, beginning in the interstices of feudalism and then breaking through its constraints, is certainly treated as a major change in the history of Europe, it appears as something like a course-correction in a historical process that was temporarily-if drastically and for a rather long time-deflected. These assumptions tend to have another important corollary, namely that towns and trade were by nature antithetical to feudalism, so that their growth, however it came about, undermined the foundations of the feudal system.

But if feudalism, according to these explanations, had derailed the progress of commercial society, the intrinsic logic 
of the market never significantly changed. From the beginning, it involved rationally self-interested individuals maximizing their utilities by selling goods for a profit whenever the opportunity presented itself. More particularly, it involved an increasing division of labour and specialization, requiring ever more elaborate networks of trade, and, above all, ever improving productive techniques, to cut costs in order to enhance commercial profits. This logic could in various ways be suppressed. But in principle, the logic of the market remained always the same, always an opportunity to be taken whenever possible, always conducive to economic growth and the improvement of productive forces, always bound eventually to produce industrial capitalism if left free to work out its natural logic.

There is no acknowldgement here of imperatives specific to capitalism, of the specific ways in which the market operates in capitalism, of its specific laws of motion which uniquely compel people to enter the market and compel producers to produce "efficiently" by improving labor productivity--the laws of competition, profit maximization, and capital accumulation. It follows that there is, according to these models, no need to explain the specific social property relations and the specific mode of exploitation that determine these specific laws of motion. There is, in fact, no need really to explain the emergence of capitalism, because it is assumed to exist, at least in embryo, from the dawn of history, if not at the very core of human nature and human rationality. People, given the chance (and when not impeded by institutional or cultural inhibitions), have always behaved according to the rules of capitalist rationality, pursuing profit and in its pursuit seeking ways to improve labor productivity, so that history has proceeded by the laws of capitalist development, in a process of economic growth sustained by developing productive forces-albeit with some major interruptions. If the emergence of a mature capitalist economy requires explanation at all, it is only an explanation of the barriers that have stood in 
the way of its development, and of the process by which those barriers were lifted.

One notable exception to the rule was the economic historian and anthropologist Karl Polanyi. In his classic work, The Great Transformation (published first in 1944) and in other works, his principal message was that the motive of individual profit associated with market exchange was never until the modern age the dominant principle of economic life, and that even where markets were well developed, a sharp distinction must be made between societies with markets, such as have existed throughout recorded history, and a "market society." In all earlier societies, "economic" relations and practices were "embedded" or submerged in non-economic social relationships - various kinds of kinship, communal, religious, and political relationships. There have been other motives driving economic activity than the purely "economic" motives of profit and material gain - the achievement of status and prestige, or the maintenance of communal solidarity - and there have been other ways of organizing economic life than through the mechanisms of market exchange; in particular what he calls the principles of "reciprocity" and "redistribution."

Only in modern "market society," Polanyi argued, is there a distinct "economic" motive, distinct economic institutions and relations, separated out from non-economic relations; and because human beings and nature-in the form of labor and land-are treated, however fictitiously, as commodities in a self-regulating system of markets driven by the price mechanism, society itself becomes an "adjunct" of the market. A market economy can exist only in a market society, that is, a society where, instead of an economy embedded in social relations, social relations are embedded in the economy.

Polanyi directly challenged Adam Smith's assumptions about "economic man" and his natural "propensity to truck, barter, and exchange," arguing that this "propensity" had 
never before Smith's own time played the dominant role he assigned to it, and that it did not regulate the economy until a century later. Where markets did exist in pre-market societies, even where they were extensive and important, they remained a subordinate feature of economic life, dominated by other principles of economic behavior. Not only that, these markets, even in the most wide-ranging and complex commercial systems, operated according to a logic quite distinct from that of the modern capitalist market.

In particular, he argued, neither the local markets nor the long-distance trade characteristic of pre-capitalist economies were essentially competitive. External trade was simply "carrying." Here, the merchant's job was to move goods from one market to another, while in local trade, commercial activity was strictly regulated and exclusive. In general, competition was deliberately eliminated because it tended to disorganize trade.

Let me clarify some points here, which may not be entirely clear in Polanyi's account. Take the example of longdistance trade, the particular form of economic activity that defined the great commercial centers which, according to all versions of the commercialization model, are supposed to have been the precursors of capitalism. This kind of trade took the form of "commercial arbitrage between separate markets." ${ }^{4}$ Buying cheap in one market and selling dear in another was the operative principle here, not competition within a single, integrated market. If there was competition, it did not take the form of competitive and cost-effective production; and the economy was certainly not driven by competition. Essentially "extra-economic" conditions, such as domination of the seas and other transport routes, or highly developed financial institutions and instruments of arbitrage, were the key to commercial advantage. So this kind of trade, largely in luxury goods for a fairly limited market, did not in itself carry an impulse to improving productivity. The main vocation of the large merchant was circulation rather than production. And even when a major commercial center like Florence 
developed domestic production, in addition to its role in servicing external mercantile activity, the basic logic of economic transactions was not essentially different. For the merchant, it was still a matter of limited production for a luxury market and a recycling of wealth in the process of circulation, rather than the creation of value in production and appropriation by maximizing surplus value in the capitalist manner.

Polanyi points out that only internal, national marketsa very late development, much resisted by local merchants and autonomous towns in the most advanced commercial centers of Europe-were to be conducted according to competitive principles. But even internal markets within early modern European nation states were for some time simply a loose collection of separate municipal markets, joined by a carrying trade hardly different in principle from long-distance, overseas commerce. Nor was an integrated internal market a direct descendant of, or a natural evolution from, the local or long-distance trade which preceded it. It was, Polanyi argues, a product of state intervention-and even then, in an economy still largely based on production by self-sufficient peasant households laboring for subsistence, state regulation continued to prevail over competitive principles.

I intend to come back to the question of the internal, competitive market and the conditions in which it emerged. For the moment, I just want to emphasize what is particularly important in Polanyi's account of the market in history. He was not, of course, alone in noting the secondary role of the market in pre-capitalist societies. Any competent economic historian or anthropologist is bound to acknowledge the various non-market principles of economic behavior that operated in such societies, from the most "primitive" and egalitarian to the most elaborate, stratified, and exploitative "high" civilizations. And other economic historians (though perhaps not as many as one might imagine) have taken note of certain changes in the principles of trade. But Polanyi's account is particularly notable for its striking delineation of the rupture between "market society" and the non-market societies which 
preceded it, even societies with markets, not only the differences between their economic logics but the social dislocations which that transformation brought about. So disruptive was the system of self-regulating markets, he insists, not only to social relations but to the human psyche, so awful its effects on human lives, that the history of its implantation had to be at the same time the history of protection from its ravages, the "protective countermoves," particularly by means of state intervention, without which "human society would have been annihilated."

Polanyi's argument in many ways represents a dramatic departure from accounts of economic development which stress the (more or less benign) continuities between ancient commerce and the modern capitalist economy even when they insist on the antagonism between "commercial" or capitalist principles and the economic (or anti-economic) logic of feudalism. But in some important respects, his account retains significant affinities with more conventional economic histories.

There is, first, more than a little technological determinism in his argument. The main theme of Polanyi's historical account is how the Industrial Revolution brought about a market society, how, in a commercial society, the invention of complex machines made it necessary to convert "the natural and human substance of society into commodities." "Since elaborate machines are expensive," he argues, "they do not pay unless large amounts of goods are produced." And the assurance of uninterrupted production required to achieve the necessary scale of production means that, for the merchant, "all factors involved must be on sale." The ultimate and most disastrous step in creating the necessary conditionsthat is, creating the market society originally required by complex machine production-is the transformation of labor into a commodified "factor."

The sequence of causation here is significant. The Industrial Revolution was "merely the beginning" of an "extreme and radical" revolution which utterly transformed society by 
commodifying humanity and nature. ${ }^{8}$ At its heart was "an almost miraculous improvement in the tools of production"; and, while it brought about a transformation of society, it was itself the culmination of earlier improvements in productivity, both in techniques and in the organization of land-use, notably enclosures in England. Although Polanyi takes issue with the belief in "spontaneous progress," he never for a moment seems to doubt the inevitability of such improvements, at least in the context of Western commercial society, with its "free institutions," especially its free urban communes, and the expansion of trade- - "the Western European trend of economic progress. $" 10$

The main outlines of Polanyi's historical narrative, then, are in some respects not so very different from less critical versions of the commercialization model: the expansion of markets goes hand-in-hand with technological progress to produce modern industrial capitalism. And although the process culminates in England, it is a general European process. For that matter, it appears that the process which led from commercialization to industrialization to "market society" may after all have been a more or less natural development in an increasingly commercialized world, a development completed only in Europe simply because certain non-economic obstacles did not here block its path. As a student of Polanyi's has explained in an account of Polanyi's lectures on "General Economic History" in the pages of Monthly Review, Polanyi argued that, in contrast to an equally commercialized East, Western European feudalism was not characterized by strong bonds of kinship, clan, and tribe, so that "when feudal ties weakened and disappeared, there was little to stand in the way of domination by market forces." And while government intervention was required to create "factor markets," "the developing market economy helped to destroy feudal economic and political institutions."

What fails to emerge from all this is an appreciation of the ways in which a radical transformation of social relations preceded industrialization, creating a historically unique im- 
perative to improve the forces of production. To say this is not just to accuse Polanyi of putting the cart before the horse. The more fundamental point is that his order of causation suggests a failure to treat the capitalist market itself as a specific social form. In fact, for all his insistence on the social consequences of the modern market, and the ways in which society has been submerged in the market economy, especially with the commodification of labor, Polanyi never actually treats the market itself as a social relation-as distinct from an impersonal mechanism which imposes itself on social relations. The specific imperatives of the capitalist market - the pressures of accumulation and increasing labor productivity-are then treated not as the product of specific social relations but as a result of (at least in Europe, more or less inevitable?) technological improvement.

I am suggesting, instead, that a capitalist dynamic rooted in a new form of social property relations both chronologically and causally preceded industrialization. In fact, a kind of "market society" - a society in which producers were marketdependent, dependent on the market for access to the means of life, labor, and self-reproduction, and subject to market imperatives-was not the result of industrialization but its primary cause. Only a transformation in social property relations which compelled people to produce competitively (and not just to buy cheap and sell dear), a transformation which made access to the means of production dependent on the market, can explain the dramatic revolutionizing of productive forces uniquely characteristic of modern capitalism.

It follows that the rise of capitalism cannot be explained as the outcome of technical improvements, or even "the Western European trend of economic progress," or any other transhistorical mechanism. It also follows that the specific transformation of social property relations which set in train a historically unique "progress" of productive forces cannot be taken for granted and still needs to be explained. 
The issue here is not just a question of disagreements about the particular historical process which created capitalism. How we understand its history has a lot to do with how we understand the thing itself. The old models of capitalist development were a paradoxical blend of transhistorical determinism and "free" market voluntarism, in which the capitalist market was both an immutable natural law and the perfection of human choice and freedom. The antithesis of such models would be a conception of the capitalist market that fully acknowledges its imperatives and compulsions, while recognizing that these imperatives themselves are rooted not in some transhistorical natural law but in historically specific social relations, constituted by human agency and accessible to change. This is the kind of conception we might expect to find in Marxism. So where has Marxism figured in these historical debates? What have Marxist historians had to say about the history of the market? The answer is that there has been as much disagreement among Marxists as between them and bourgeois historians. Many Marxists (not least Marx himself in his earlier writings ${ }^{12}$ ) have been no less wedded than anyone else to the old commercialization model, often, perhaps, with a stronger dose of technological determinism. Others have been very critical of that model, though even here, strong residues remain. The debate is still in progress, and there is still much work to be done.

The single most important debate among Marxists on the relevant questions is the so-called "Transition Debate" sparked off by an exchange between Paul Sweezy and Maurice Dobb in Science and Society in the early $1950 \mathrm{~s} .{ }^{13}$ Among the main themes of the debate was the role of towns and trade in the transition, and particularly whether trade, especially the growth of long-distance East-West trade in the manner suggested by Pirenne, was the solvent of feudalism-in other words, whether the "prime mover" was external to the primary relations of feudalism-or whether the causes of that dissolu- 
tion and the rise of capitalism must be found within those relations, the relations between lords and peasants.

Sweezy argued that feudalism, for all its inefficiencies and instabilities, was intrinsically tenacious and resistant to change, and that the main moving force in its dissolution had to come from outside. The feudal system could tolerate, and indeed required, a certain amount of trade; but with the establishment of localized urban trading and transshipment centers based on long-distance trade (about which Sweezy cited the authority of Henri Pirenne), a process was set in train which encouraged the growth of production for exchange, in tension with the feudal principle of production for use. But this by itself was not enough to bring about capitalism. Sweezy here made the important point that, while "We usually think of a transition from one social system to another as a process in which the two systems directly confront each other and fight it out for supremacy," it would be a "serious error" to think of the transition from feudalism to capitalism in these terms. ${ }^{14}$

Sweezy did not propose to explain the second phase of the process, but he raised some critical questions about explanations offered by others. Two in particular stand out. First, he expressed skepticism about the plausibility of the viewfollowing from the conventional interpretation of Marx's theory of the "really revolutionary way" to industrial capitalism-that industrial capitalists rose from the ranks of petty producers, proposing instead that we should understand the "really revolutionary way" as a process in which the producer, instead of growing from petty producer into merchant and capitalist, "starts out as both a merchant and an employer of wage-labour," in which capitalist enterprises are launched fully fledged instead of in a gradual process of growth out of the putting-out system. ${ }^{15}$ The second point was that even the generalization of commodity production could not account for the rise of capitalism and that highly developed commodity production-as, for instance, in medieval Italy or Flanders-did not necessarily produce capitalism. ${ }^{16}$ 
Sweezy's opponents, especially Maurice Dobb and Rodney Hilton, argued instead that trade in itself was not the solvent of feudalism; and Hilton in particular pointed out that Pirenne's argument had in any case been shown to be empirically flawed. They insisted that the "prime mover" in the transition which Sweezy was looking for was to be found in the relations between lords and peasants. Hilton in particular spelled out the ways in which money, trade, towns, and even the so-called "commercial revolution" were integral to the feudal system. This meant that, while there was undoubtedly a complex process in which they contributed to the transition, they could not be regarded as antithetical or inimical to feudalism and hence as its principal solvent.

Both Dobb and Hilton, in various ways, suggested that the dissolution of feudalism and the rise of capitalism resulted from the liberation of petty commodity production from the fetters of feudalism, with the help of class struggle between lords and peasants. Dobb, for example, argued that, while class struggle did not, "in any simple and direct way," give rise to feudalism, it did serve to

modify the dependence of the petty mode of production upon feudal overlordship and eventually to shake loose the small producer from feudal exploitation. It is then from the petty mode of production (in the degree to which it secures independence of action, and social differentiation in turn develops within it) that capitalism is born. ${ }^{17}$

Similarly, Hilton suggested that the pressures imposed by lords on peasants to transfer surplus labor were the root cause of improved production techniques and the basis for the growth of simple commodity production, while peasant resistance to those pressures was crucially important to the process of transition to capitalism, "the freeing of peasant and artisan economies for the development of commodity production and eventually the emergence of the capitalist entrepreneur.",18 
This summary is, of course, a gross abbreviation and simplification of the complex arguments offered by the participants in the debate; but it should be enough to raise some critical questions about the assumptions on which each side was operating. At first glance, it is Sweezy who seems to show the greatest affinity to the commercialization model, while his opponents seem to depart from it. But the issue is not so simple. On closer inspection, it is not at all clear that Dobb and Hilton are challenging all the basic assumptions of the commercialization model, and some of the questions raised by Sweezy go to the heart of the problems they leave unresolved. One point stands out in the arguments of Dobb and Hilton: the transition to capitalism is a matter of liberating or "shaking loose" an economic logic already present in simple commodity production. We are left with the overwhelming impression that, given the chance, the commodity-producing peasant (and artisan) will grow into a capitalist. The center of gravity in this argument may have shifted away from the city to the countryside, and class struggle has been given a new role; but how different are the assumptions underlying this argument from some of the main premises of the commercialization model? How far are we from the premise that the capitalist market is an opportunity rather than an imperative, and that what requires explanation in accounting for the rise of capitalism is the removal of obstacles, the breaking of fetters, not the creation of a wholly new economic logic?

Here the problems that troubled Sweezy in his confrontation with Dobb's argument are very much to the point. First, the habit of treating transitions as a confrontation between two antithetical modes of production has far too often been an excuse for begging the question. As Sweezy suggested, while it may have a different meaning in the transition from capitalism to socialism, this habit is particularly problematic in dealing with the transition from feudalism to capitalism. As we have seen, the commercialization model and other related explanations effectively assume the existence of capitalism, or a capitalist rationality, in order to explain its emergence. 
Feudalism is confronted by an already existing capitalism, at least in embryonic form, whose coming into being is never explained. The explanations offered by Marxists like Hilton and Dobb, while in many ways devastating to the commercialization model and to its assumptions about the antithesis of feudalism and commerce, have not entirely escaped from this trap, still in some important respects assuming the very thing that needs to be explained.

Nor do they offer an entirely convincing response to the question raised by Sweezy about the failure of advanced commercial centers such as those of Italy and Flanders. Here again there is a tendency to take capitalism for granted by simply explaining the obstacles which prevented these commercial cities from reaching maturity. The question posed about Flanders or Italy is not so much why and in what circumstances did capitalist imperatives impose themselves on economic actors, as they did in England, but rather why and in what ways were economic actors in the "failed" transitions unwilling or unable-not least for ideological or cultural reasons-to break away from their attachment to feudalism in order to create a new social form. ${ }^{19}$

There is also good reason for Sweezy's skepticism about the "really revolutionary way." This idea appears in Dobb particularly (though not exclusively) in the form of capitalist farmers rising from the ranks of the yeomanry. Again, the problem is that these rising yeomen tend to be depicted as more or less freely choosing the capitalist road, once released from feudal impediments, while capitalism is treated as a more or less organic growth out of petty commodity production-even if bourgeois revolutions may be required to remove the final obstacles. Yet there must be something more to account for the disposition of producers to behave like capitalists than simply their liberation from restraints or their growth from "middling" to large proprietors, and there is a qualitative difference between petty commodity production and capitalism which remains to be explained. 
What the Transition Debate left unexplained-the question that was never really asked - was how and in what circumstances producers became subject to market imperatives. There has, however, been a further installment in the ongoing debate among Marxists. The historian Robert Brenner, taking up the challenge of the Transition Debate, has produced an important body of work which seeks to explain the transition from feudalism to capitalism without reading capitalist principles back in to pre-capitalist societies and without assuming the very thing that needs to be explained. He also rejects the model of the transition from feudalism to capitalism in which two antagonistic modes of production confronted each other. There was no embryonic capitalism in the interstices of feudalism-either in pre-capitalist forms of trade or in petty commodity production treated as a kind of proto-capitalism. Brenner criticizes other accounts of the transition for neglecting the "internal logic and solidity" of pre-capitalist economies and proceeding as if economic actors will adopt capitalist strategies when given the chance-a criticism which would, though he never says it in so many words, presumably apply as much to the rising-petty-commodity-production theory as to the commercialization model. Brenner takes this insight further, however, not by looking for some external impetus to the dissolution of feudalism (in the context of certain property relations, for example, trade could and did lead to tighteningrather than loosening pre-capitalist property forms) but by looking for a dynamic internal to feudalism which does not itself presuppose an already capitalist logic. Class struggle figures prominently in his argument, as it did in Dobb's and Hilton's, but here it is not a question of liberating an impulse toward capitalism. Instead, it is a matter of lords and peasants, in certain specific conditions peculiar to England, involuntarily setting in train a capitalist dynamic while acting to reproduce themselves as they were, creating a situation in which producers were subjected to market imperatives-not the opportunity to produce for the market and grow from petty 
producers into capitalists but the need to specialize for the market and to produce competitively-simply in order to guarantee access to the means of subsistence.

There is no room to go into detail here. ${ }^{20}$ It is enough to say that Brenner's explanation has to do with the very specific conditions of English property relations, in which an exceptionally large proportion of land was owned by landlords and worked by tenants whose conditions of tenure increasingly took the form of economic leases, in effect obliging them to compete not only in a market for consumers but in a market for access to land, and to produce competitively in order to pay economic rents. At the same time, landlords in England had been demilitarized before any other aristocracy in Europe, and the English state was uniquely centralized, without the "parcellization of sovereignty" characteristic of feudalism and its successor states. This meant that, although the state served the aristocracy as an instrument of order, the ruling class was unusually devoid of autonomous "extra-economic" powers, or what Brenner calls "politically constituted property," the kinds of independent political, juridical, and military powers by means of which exploiting classes in pre-capitalist societies-such as feudal lords-typically appropriated surplus labor. This distinctive landed class became increasingly dependent on the productivity of their tenants, rather than on exerting coercive power to squeeze more surplus out of them. As competitive "market forces" established themselves, less productive farmers went to the wall, and together with direct coercive intervention to evict them or to extinguish their customary rights, this accelerated the polarization of English rural society into larger landowners and a growing propertyless multitude. The famous "triad" of landlord, capitalist tenant, and wage laborer was the result, and with the growth of wage labor the pressures to improve labor productivity also increased. The same process created a highly productive agriculture capable of sustaining a large population not engaged in agricultural production, but also an increasing propertyless mass, which would constitute both 
a large wage-labor force and a domestic market for cheap consumer goods-a type of market with no historical precedent. This is the background to the formation of English industrial capitalism.

Although Brenner has clearly been influenced by Dobb and Hilton, the difference between his argument and theirs should by now be clear. Again, the operative principle in his argument is compulsion or imperative, not opportunity. If, for example, the yeoman-farmer plays a role here, it is not as the bearer of an opportunity but as the subject of an imperative. Yeomen were typically the very kind of capitalist tenants who were subject to the competitive pressures of the English triad; and even owner-occupiers would be subject to those pressures once the competitive productivity of agrarian capitalism set the terms of economic survival. Both landlords and tenants came to depend on success in the market, as the former relied on the profits of the latter for their rents; and both had an interest in agricultural "improvement," the enhancement of productivity by means of innovative land use and techniques, which often implied, among other things, enclosure-not to mention the exploitation of wage labor.

In one of the additions to the Transition Debate, another contributor inadvertently illustrates the difference between the market-as-opportunity model and the market as imperative-though perhaps in a way which a specialist like Hilton would have avoided. John Merrington, in his important article on the structural role of towns in feudalism, suggests that, although the transformation of feudal surplus labor into money rents did not in itself alter the fundamental nature of feudal relations, by helping to fix surplus labor to a constant magnitude it "stimulated the growth of independent commodity production." ${ }^{21}$ This proposition seems to be based less on empirical evidence than on the presupposition that petty producers would choose to act like capitalists if given the chance. Brenner, in contrast, shows how unfixed, arbitrary rents, acting as economic rents responsive to market imperatives, stimulated the development of commodity produc- 
tion, the improvement of productivity, and self-sustaining economic growth. Elsewhere, as in France, where peasants typically enjoyed possession of land at fixed and nominal rents, no such stimulus existed.

In a sense, Brenner has also answered Sweezy's question about the "really revolutionary way." The capitalist tenant in England was not just a petty producer who had grown into a capitalist. His specific relation to the means of production, the conditions in which he had access to land itself, made him from the start a capitalist, a producer subject to market imperatives and typically an employer of wage labor.

The contrast with France is illuminating. Here, the aristocracy long retained its hold on politically constituted property or "extra-economic" powers of exploitation; and when feudalism was replaced by absolutism, these powers were not replaced by purely economic exploitation or capitalist production. Instead, the French ruling class gained new extra-economic powers as the absolutist state created a vast apparatus of office by means of which a section of the propertied class could appropriate the surplus labor of peasants in the form of a tax. And even then, at the height of absolutism, France remained a confusing welter of competing jurisdictions, as nobility and municipal authorities clung to the remnants of their autonomous feudal powers, the residues of feudal "parcellized sovereignty." In these conditions, the preferred economic strategy was still to squeeze the peasants by extraeconomic means rather than to encourage competitive production and "improvement." There was no impetus to capitalist development comparable to England's until England itself succeeded in imposing its competitive pressures on an international economy. This was to be the pattern of development in other capitalist societies too, as competitive pressures from outside, in an international system, compelled other states to encourage economic development.

It is worth noting, too, that the integrated national market which Polanyi described as the first kind of market to operate on competitive principles developed in England long 
before anywhere else, while France had to await the Napoleonic era to remove internal barriers to trade. The important point about this is that the development of a competitive national market was a corollary, not a cause, of capitalism and "market society." The evolution of a unified and competitive national market reflected changes in the nature of the mode of exploitation and the nature of the state. So, for example, in France, the persistence of "extra-economic" powers of exploitation, not only in the form of state-office but also the remnants of old aristocratic jurisdictions or other corporate powers and privileges inherited from feudalism, meant that neither the state nor the economy was truly integrated. This corporate fragmentation of society was as much a part of absolutism as the centralized bureaucracy which dominates conventional stereotypes of the absolutist state. In England, where there was a clear separation between the political, coercive powers of the state and the exploitative powers of propertied classes which derived their wealth from purely "economic" forms of exploitation, the private economic powers of the ruling class did not detract from the political unity of the state, and there was both a truly centralized state and an integrated national economy.

\section{VI}

Brenner's argument, then, by showing how direct producers became subject to market imperatives, explains the context in which the very nature of trade and markets was transformed, acquiring an entirely new economic role and a new systemic logic. This happened long before industrialization and as a precondition to it. Market imperatives, in other words, imposed themselves on direct producers before the mass proletarianization of the work-force and, in fact, were a decisive factor in creating a mass proletariat, as "market forces," supported by direct coercion in the form of political and judicial intervention, created a propertyless majority.

But proletarianization, which meant the complete commodification of labor power, did confer new and more far- 
reaching coercive powers on the market by creating a working class that was completely market-dependent and completely vulnerable to market disciplines, with no mediations and no alternative resources. Nor, of course, is it enough to say that both capital and labor were subject in their various ways to the impersonal forces of the market. The market itself became a major axis of class division between exploiters and exploited, between buyers and sellers of labor power, and a new coercive instrument for capital, the ultimate discipline in its control of labor.

The way in which "market society" established itself in the in tervening period has been most vividly described by E.P. Thompson. In his work, the establishment of "market society" comes to life, not only as a process of proletarianization, particularly in his classic work, The Making of the English Working Class, but also in his writings on the earlier eighteenth century, as a living confrontation between "market society" and alternative values and practices. The implantation of "market society" also appears as a confrontation between classes, between those whose interests were expressed in the new political economy of the market, together with its philosophy of "improvement," and those who struggled to contest them from a vantage point that put the right of subsistence before the imperatives of profit.

For those who have wondered why Thompson, after The Making of the English Working Class, moved back into the eighteenth century instead of forward beyond the 1830 s to a fuller account of industrialization, the answer must be that he was trying to explain the establishment of capitalism as a social form, and not some neutral technical process called "industrialization." He was particularly interested in the eighteenth century as the moment when the capitalist transformation of property relations was being consolidated and was playing itself out in the articulation of a new capitalist ideology more self-conscious and explicit than ever before. It was also a moment when the contestation of the new economic principles had not yet been submerged in a hegemonic ideology, 
the political economy of the market, which would soon infiltrate even some of the most radical opposition to capitalism.

Thompson suggests that in eighteenth-century England the market was in fact the main arena of struggle. This was so for reasons very specific to this "transitory" moment in English history. On the one hand, this was a moment of "free" labor, subject neither to pre-capitalist, extra-economic forms of domination nor as yet, in general, to the new disciplines of the factory, so that people for a short time still controlled "their own immediate relations and modes of work." ${ }^{22}$ On the other hand, "they had very little control over the market for their products or over the prices of raw materials or food." This is why social protest was so often directed at the market. People (often women) opposed not only what they regarded as unjust prices but illegitimate and immoral market practices-practices designed to increase profit, which from the vantage point of "market society" and capitalist rationality seem perfectly normal today but which violated certain customary expectations about rights of access to the means of life.

In some of these protests, we can also see opposition to the transformation of the market from a visible and more or less transparent institution into an "invisible hand." The market with which people had been most familiar was a physical place where people put commodities on offer for other people to buy, according to principles still to some extent governed by custom, communal regulation, expectations about the right to subsistence, and what Thompson famously called "the moral economy of the crowd." Now it was becoming a mechanism beyond communal control, as the transparency of market transactions was supplanted by the mysteries of a "self-regulating" market, the price mechanism, and the subordination of all communal values to the imperatives of profit.

Thompson also shows how the new ideology of political economy, together with the new conceptions of property and the ethic of profit and "improvement" on which it was based, were increasingly enforced by state repression. The courts would put reasons of "improvement" - the proprietor's right 
to profit by increasing productivity-above customary userights or the right to subsistence. And the civil authority reacted more violently (especially in the wake of the French Revolution) to protest against unjust prices and market practices. Coercion by the state, in other words, was required to impose the coercion of the market.

\section{VII}

A lot still remains to be learned about the role of markets, cities, and trade in the history of capitalism; but even to acknowledge that capitalism was not an organic growth out of age-old forms of commerce, nor a result of technological development, and to recognize all the consequences of the social relations that constitute the capitalist market, has major implications.

I am convinced, for example, that various political programs of the left-from social democratic demands for a more "social" market in the context of capitalism, to somewhat more radical theories of "market socialism"-are still in some ways based on illusions about the nature of the market as a sphere of opportunity and choice, and a failure to consider the full consequences of treating the market as an economic regulator. I still remember-though the heady days of the Communist collapse already seem very distant-how idealistic democrats in Eastern Europe responded to warnings about the market from the Western left (at a time when there still seemed to be an anti-market left in the West and still some chance of dialogue between them and more progressive forces in the former Communist countries). When people warned that "the market" means not only supermarkets with lots of choice but mass unemployment and poverty, the reply would be, "Yes, of course, but that's not what we mean by the market." The idea was that you could pick and choose what you want from the self-regulating market. The market can act as a regulator of the economy just enough to guarantee some "rationality," some correspondence between what people want and what is produced. The market can act as a signal, a 
source of information, a form of communication between consumers and producers; and it can guarantee that useless or inefficient enterprises will shape up or fall. But we can dispense with its nastier side.

All this may seem as naive to many Eastern Europeans now as it did to some Western Marxists then; but it is not at all clear that many on the Western left today are any less inclined to think that the market as an economic regulator is amenable to that kind of choice between its beneficent disciplines and its more destructive consequences. It is difficult to explain in any other way the notion of "market socialism," or even the less utopian social democratic conception of the "social market," in which the market's ravages can be controlled by state regulation and an enhancement of social rights.

I do not mean to say that the "social market" is no better than free market capitalism. Nor do I mean to suggest that certain institutions and practices associated with the market could not be adapted to a socialist economy. But it's no good refusing to confront the implications of the one irreducible condition without which the market cannot act as an economic discipline: the commodification of labor power-a condition which places the strictest limits on the "socialization" of the market and its capacity to assume a human face. ${ }^{23}$

The market today is still acting not only as an "impersonal" imperative but also as a direct instrument of class power manipulated by capital in its control of labor, not to mention as a medium of a new imperialism, in which advanced capitalist economies, with the help of the state, are imposing market "disciplines" on the Third World and on the "new democracies." To avoid the ravages of market society will require greater transformations than Polanyi had in mind, but as a historically specific social form capitalism may also be more open than he imagined to contestation and another "great transformation."

At this moment in the "long decline," capitalists themselves-in their increasingly desperate demands for "flexibility"-seem closer than ever before to admitting that the 
imperatives of the capitalist market will not allow them to prosper without depressing the conditions of workers and degrading the environment. In these circumstances, socialism may turn out to be less un realistically utopian than is a "social" capitalism.

\section{NOTES}

1. See, for example, Henri Pirenne, Medieval Cities: Their Origins and the Revival of Trade (Princeton, 1952).

2. I have argued that Max Weber falls into this category in my forthcoming book, Democracy Against Capitalism: Renewing Historical Materialism (Cambridge, late 1994 or early 1995).

3. See Robert Brenner, “Agrarian Class Structure and Economic Development in Pre-Industrial Europe," in T.H. Aston and C.H.E. Philpin, eds., The Brenner Debate: Agrarian Class Structure and Economic Development in Pre-Industrial Europe (Cambridge, 1985), p. 10.

4. Eric Kerridge, Trade and Banking in Early Modern England (Manchester, 1988), p. 4.

5. Karl Polanyi, The Great Transformation: The Political and Economic Origins of Our Time (Boston, 1957), p. 76.

6. Ibid., p. 42.7. Ibid., p. 41.

8. Ibid., p. 40.9. Ibid., p. 33.

10. Ibid., p. 37.

11. Daniel R. Fusfeld, "The Market in History," MR 45, no. 1 (May 1993): 6.

12. For a discussion of the changes in Marx's conception of history and the development of capitalism, his changing views on a range of issues from the division of labor to bourgeois revolution, see George Comninel, Rethinking the French Revolution: Marxism and the Revisionist Challenge (London, 1987): and Robert Brenner, "Bourgeois Revolution and Transition to Capitalism," in A.L. Beier, et al., eds., The First Modern Society (Cambridge, 1989).

13. The whole debate, which brought in other major Marxist historians, was later published, with some additions, in ed. Rodney Hilton, ed, The Transition from Feudalism to Capitalism (London, 1976).

14. Ibid., p. 49.

15. Ibid., p. 54 .

16. Ibid., pp. 106-7.

17. Ibid., p. 59.

18. Ibid., p. 27.

19. See, for example, Hilton in Transition, pp. 157-9.

20. Brenner's most important account of the transition can be found in The Brenner Debate.

21. Hilton, p. 179.

22. E.P. Thompson, Customs in Common (London and New York, 1991), p. 74.

23. For a discussion of this point, see David McNally, Against the Market (London, 1994). 